\title{
MEASURES OF THE STATE FOR INTRODUCTION DEOFFSHORIZATION IN STOCK MARKET OF UKRAINE
}

\author{
Oksana KIKTENKO' \\ Classical Private University, Ukraine
}

\begin{abstract}
The purpose of the article is to improve monitoring and control in the system of state regulation of the stock market and to develop practical recommendations for an integrated mechanism, which is aimed at stabilizing and improving the functioning of its state regulators. Methodology. The following research methods were used: analysis and synthesis - to identify the most important factors affecting the operation of the stock market, consolidation of trends and evaluation the effectiveness of individual measures of government regulation; statistical analysis, comparison and generalization - to study the effectiveness of the regulatory bodies of the stock market in Ukraine. Results. It's necessary to introduce deoffshorization, which is a tool of economic mechanism of the development of state regulation of the stock market and optimal combination of the tax burden, comfortable business environment and the country's stock market capitalization. Practical significance. Practical recommendations on the need to introduce deoffshorization in the stock market of Ukraine are seen as a tool of economic mechanism for further state regulation development of the stock market, used in the formation of proposals to introduce deoffshorization in the stock market in the Regulations of the National Commission on Securities and Stock Market. Value/originality. Implementation of the deoffshorization in the stock market will allow the State to strengthen the protection of investors' rights, it is a strategic goal of Ukraine, as well as to strengthen the local stock market and increase its credibility among the population.
\end{abstract}

Key words: state regulation, participants of stock market, regulators of the markets, efficiency, integration, listing, self-regulation.

\section{JEL Classification: G15, G18, E 44}

\section{Introduction}

The by lack of a common the position of stock market separate establishments interferes with development of effective policy deoffshorization of it's. It is necessary to introduce restrictions for transactions in this market between state structures and the commercial organizations in which shareholders or executives are close relatives of heads of the respective government institutions; to check and carry out monitoring of the companies with the state participation regarding the existence of corruption schemes and money laundering through the offshores.

\section{The problems of deoffshorization in stock market}

The problems how of increase the level of stock market transparency are investigated. Advantages liquidity of stock market increase are considered. The priority directions of process of deregulation and liberalization are suggested, etc. Reduction of direct state intervention.

In general it is possible to point out various problems of deoffshorization in stock market. Concerning export of the capitals to the offshore received illegally, rather negative availability the consolidated position which completely corresponds to the international trends of anti-offshore.

However the illegal capital most often is transformed by means of offshore financial policy into legal. Concerning rather aggressive minimization of the taxation corporate sector with use of offshore networks use. The uniform point of view isn't available. This position rather debatable. Along with opponents of such policy encouragement there are their obvious supporters, who claim, that the application of the taxation minimization schemes is conventional for the international practice, they increase stock market competitiveness.

Besides, the use of the offshore serves as protection of property against raider captures by law enforcement agencies and criminals. In offshore jurisdictions there is an independent judicial system, clear and convenient laws for doing business, bigger trust to foreign banks and other investors. At last, one more argument of offshore supporters is the statement that the earned capital can't be effectively used in economy today.

Corresponding author:

${ }^{1}$ Department of Public Administration and Land Registry, Classical Private University.

E-mail: kiktenko_@list.ru 
Currently Ukraine can not do without use of offshore so far, but such an opinion is lobbied by shadow structures. Such point of view is expressed by part of business and wealthy and it has to force public authorities to begin solving more actively the deoffshorization problems in stock market. However it should be noted that supporters of the offshore use seek to create a tax oasis (for example, investment companies, innovative funds, etc.) which would allow partly to compensating investment climate of Ukraine.

\section{The state programs soft deoffshorization}

Deoffshore structures in stock market are first of all, the centers of getting profits which, they have to receive in Ukraine and hide from taxation. The state programs soft deoffshorization are made under the influenced of a pro-offshore view out also some official. They assume the cancellation of all bans and development of the capital market, which to place of the companies shares during the privatization in the market, providing thereby enables liquidity, stimulation of long-term insurance and voluntary pension savings, its infrastructure improvement of the financial markets, etc.

It will promote the return of business to Ukraine. Thanks to these measures until the number of the companies in national market to 2016 has to increase from 6 to $100 \%$, the amount of securities trading of the Ukrainian companies in stock market has account for than $90 \%$ instead of 50\%, and the amount of the pension savings invested in shares in the Ukrainian stock market had to approach up to $50 \%$. At the same time, unlikely these offers can be considered as just deoffshore as they don't include the use of offshore financial networks.

The main directions of deoffshorization policy can become as the measures promoting the offshore as well as the measures which motivate business to refuse to export assets in these jurisdictions. At the same time, the priority is given to stimulate the stock market measures. Among them the expansion of tax benefits for private investors is offered, for example, introduction of privileges for investments into securities (Christofields, 2003).

Disproportions of national stock market, which need adjustments, the following: diagnostics of the main stages of stock market monitoring; essential prevalence of unorganized stock market over organized, and external investors - over internal; domination corporate control in stock market and investment limitation of his secondary segment; high specific weight of the enterprises of key branches of economy in the general capitalization and in a pool of national «blue chips»; considerable concentration of the market (domination of small group of issuers) both on trade volumes, and on capitalization indicators; underestimation of many companies of issuers by the market owing to incomplete insufficient of information about results of their activity and investment intentions (Federation of European Securities exchanges statistics methodology, 2010).
The monitoring diagnostics of stock market has to be carried out during monitoring procedure and stability monitoring of stock market. Financial monitoring of stock market is part of supervising functions of the government. His main objective is to provide bodies of stock market with information, reflecting results of activity in this market and influence of the factors, defining stability of a banking system.

The main objectives of monitoring are: collecting and accumulation of information which reflects the main indicators of economic development of the country in the context of dynamic development of stock market; analysis and forecast of financial stability indicators of stock market; assessment of system of stock market risks; identification and assessment extent of influence of government departments, which define the stability of stock market; assessment of efficiency of the actions, extent which are carried out within the state of stock market regulation (Polishchuk, 2013).

\section{Methodology the comparisons and generalization}

Based on recent experience of the last years, efficiency of the state tools use in overcoming of stock market crisis depends on the purposes coherence with tasks and mechanisms of structural, institutional and tax reforms. Considering destructive impact of system crises, it is necessary not only to fight against consequences of their action, but also to foresee them.

The use of the state tools for deoffshorization introduction in stock market is appropriate at the following levels:

- deoffshorization at the macroeconomic level - use of financial instruments;

- deoffshorization at a microeconomic level - use of operational tools;

- deoffshorization which is characterized by full-scale budgetary and financial stabilization of stock market, which leads to stabilization of inflation with the use of structural tools.

The acceptance of similar measures would certainly an important step for the saving of the capitals in Ukraine. However, these measures won't become a turning point for reorientation of the investor to the Ukrainian jurisdiction, where, at least, serious reasons remain attract which the Ukrainian capitals to offshores. Besides, for the realization of these actions it is necessary to make essential changes into the current legislation wich is also a difficult task.

A number of the legislative initiatives aimed at deoffshorization of economy, are prepared be separate departments. For example, legislators offered to create certain conditions of the foreign economic agent for those firms which use foreign jurisdiction.

The obligatory requirement to the offshore companies is offered to introduce to show all the beneficiaries and to explain, why they are registered in low-tax jurisdictions, 
certain restrictions access to any kind off budget money, to participation in competitions of state procurements.

It is necessary to provide competent authorities with access information about participants of stock market in all cases, which identifies founders, trustees and beneficiaries of foreign trusts, control of which is exercised in Ukraine or trustees of which are residents, as well availability of the international standards of an exchange and protection of tax information. The deoffshorization policy has fragmentary not always consecutive and very often declarative character. It is proved the above mentioned analysis (Rebrik, 2012).

Therefore we offer a system of measures on deoffshorization in stock market which contains several original offers which can significantly weaken the level of degree deoffshorization, and it also supplements and develops some proposition. At the same time it will be a question generally about the deoffshorization connected with legal use of the offshore although. The proposed measures should also weaken «illegal offshore economy».

The deoffshorization program in stock market has to be based on several system actions:

- cardinal improvement of conditions for implementation of the state supervision, including institutional and political reforms;

- tax maneuver due to the revision of the tax system with transfer of the center of gravity of investors' tax incentives into the Ukrainian jurisdiction;

- strengthening the level of responsibility for the violation of the tax laws, which complies with the international practice; improvement of the international cooperation regarding an exchange of tax information and that of fiscal violations investigations.

The important direction of stock market state regulation of Ukraine is systematic questions of the central depositary, in particular, the definition of the consolidating structure based on the State National Depositary of Ukraine.

The universal practice shows that, as a rule, there is a single depositary in the developed countries, which usually is a private property. So in EU countries there are separate cases of the organization of Central Securities Depositories. So, the Czech Republic has three depositaries (two private - for corporate securities, one - is a property of the central bank for the state securities). Spain has four private depositaries (for corporate and state securities at the same time) where the central bank's share accounts for 5\% (Roxburgh, Lund, 2010).

There are different models of the organization of Central Securities Depositories in some countries. So, four countries of the CIS have a single central depositary for corporate and state securities: in Georgia and Moldova the central depositary is $100 \%$ private, in Kazakhstan is $51 \%$ private ( $49 \%$ is a property of the Central bank), in Belarus - $100 \%$ state ownership.

As for the other developing countries such as Argentina, Brazil, Chile and South Korea, they have a single 100\% private central depositary. It is important to point out the advantages of a single depositary, which results in cost-effectiveness at the expense of large scales because of a great number of transactions and creating positive conditions for consolidation of administrative divisions functions of securities market (depreciation), as well as consolidations of depositary and clearing functions, which enables to reduce risks. The transparency of stock market is thought to be a necessary condition of its development in Ukraine.

There are problems of regulation and information disclosures in the stock market of Ukraine: the investment public does not always have full access to necessary information and does not always receive it on time; participants of the stock market do not understand the importance of the systematic and complex publication of information, which results in regular, reliable, full and actual information in the market.

\section{Findings}

For the purpose of improvement of stock market information transparency of Ukraine, it is provided: practical introduction of the electronic document flow with the application of a digital signature by the participants of the stock market in their activities and reports; obligatory disclosure of the securities by issuers who have made their public placement and information about the results of the activities according to the standards; toughening of requirements as to disclosure of information by issuers, first of all, by those whose securities have undergone the procedure of listing or are speculated in the stock exchanges; legislative regulation improvement of questions what information must be referred to as to insider, definition of persons who are considered insiders, as well as the responsibility for the use (disclosure) of insider information.

The stock market of Ukraine by the level of maturity and risks is related to the markets which are at an initial stage of its development. Because of considerable currency, price and credit risks which specify the stock market of our country, foreign investors' interests in operations of the Ukrainian securities purchase and sale have been gradually decreasing. The Ukrainian stock market has to compete for volumes of investment resources with other stock markets.

The increase of competitiveness and civilized integration with the international capital markets have to be priorities of stock market state regulation in Ukraine. The equal opportunities for participants on conditions of fair competition, more favorable state policy of regulation and taxation than in other countries have to be provided. In the longer term, the Ukrainian dealers of securities have to transform into full-function, financially steady investment institutes, which will provide their clients with a wider and better range of financial services and products.

The stock market of Ukraine has to become part the world market of financial resources, providing foreign investors with the reliable mechanism for implementation of portfolio investments into the economy of Ukraine. 
The insufficient level of population's involvement into the financial area is explained, in particular, by the low level of publicity and trust to financial instruments.

For the increase of information transparency in the stock market, it is provided: the definition of target audience for carrying out the actions aimed at the involvement of the population in the stock market, as well as development of methodical recommendations for each of target groups; the preparation and realization of the actions aimed at promoting information among citizens on their rights and opportunities in the stock market for personal savings investments; introduction of educational programs for heads of local councils and public administrations, jointstock companies and potential issuers.

\section{Conclusions}

Regulators should control additionally a number of indicators of such operations demonstrating the increase of transparency of the stock market: liquidities, placement costs, a ratio between expenses of placement and the attracted financial resources, etc. Also, the state has to control in some cases the volume of the raised funds according to the IPO programs, especially concerning the placement of a big portfolio of securities of the enterprise, strategically important for Ukraine.

The increase in liquidity of the stock market assumes unloadings of the its built-up system problems, in particular: ensuring stabilization of functioning, the increase liquidity level of securities market and expansion of a potential investors circle (insurance companies, pension funds, legal entities); the development of innovative financial instruments of the securities market, application of technologies of securitization; introduction of mortgage securities to economic circulation which can be issued directly by mortgage creditors or mortgage institutions of the second level.

The regulation of stock market is currently undergoing the process of deregulation and liberalization, that is the reduction of direct state intervention. However, the process of deregulation doesn't mean full refusal by the state to regulate the stock market and consolidate the exchanges, but gradual transition from administrative to indirect methods of regulation and transfer of part of the regulating powers to market systems of regulation, including self-regulatory organizations.

Thus, the creation of one or the other mechanism of stock market regulation is influenced by the integrated set with institutional, national historical and macroeconomic background. Therefore, the requirements which the system of stock market state regulation has to correspond to, including a transition period, have historical nature. They depend on the power of the state and maturity of participants, as well as the objectives which we set up when the mechanism of stock market state regulation was defined.

\section{References}

Christofields Ch. (2003). The link between adherence to international standards of good practice, foreign exchange spreads, and ratings. IMF Working paper, (74): 31-37.

Federation of European Securities exchanges statistics methodology (2010). Version 5.2. (1) : 25 - Retrieved from: http://www.fese.eu/_lib/files/FESE_Statistics_Methodology_5_2_January10_FINAL.Pdf.

Polishchuk V. (2013). Topical issues of the organization of the external state financial control: the world experience and the present situation in Ukraine. Innovations, (12): 104-106.

Progress in the Implementation of the G 20 Recommendations for Strengthening Financial Stability: Report of the Financial Stability Board to G 20 Finance Ministers and Central Bank Governors 10 April 2011. [Electronic resource]. Retrieved from: http://www. financialstabilityboard.org/publications/r_110415a.pdf.

Rebrik Y. (2012). Methodical aspects of stress testing of the bank's liquidity, taking into account the standards of Basel III. Finances of Ukraine, (4): 89-97.

Roxburgh Ch., Lund S. (2010) Global capital markets: Entering a new era. McKinsey Global Institute:31-38. Retrieved from: http://www.-mckinsey.com/mgi /publications/fifth_annual_report_Executive_Summary.asp

U.S. Securities and Exchange Commision. - Mode of access: http://www.sec. gov/

World Federation of exchanges: Statistics; Statistics Definitions. - Retrieved from: http://www.world-exchanges.org/ statistics/statistics-Definitions.

\section{Оксана КИКТЕНКО}

\section{МЕРЫ ГОСУДАРСТВА ПО ВНЕДРЕНИЮ ДЕОФШОРИЗАЦИИ НА ФОНДОВОМ РЫНКЕ УКРАИНЫ}

Аннотация.Цельюроботыявляется совершенствованиемониторинга и контролявсистемегосударственного регулирования фондового рынка и разработка практических рекомендаций по комплексному механизму, направленному на стабилизацию и повышение эффективности функционирования его государственных регуляторов. Методика исследования. Были использованы следующие методы исследования: анализ и 
Vol. 2, No. 2, 2016

синтез - выявить наиболее важные факторы, влияющие на работу на фондовом рынке, консолидацию тенденций и оценки эффективности отдельных мер государственного регулирования; статистический анализ, сравнение и обобщение - для изучения эффективности регулирующих органов фондового рынка в Украине. Результаты исследования. Необходимость внедрения деофшоризации, что представляет собой инструмент экономического механизма обеспечения развития государственного регулирования фондового рынка, оптимальную комбинацию налоговой нагрузки, удобных условий для ведения бизнеса и капитализации фондового рынка страны Практическое значение. Практические рекомендации о необходимости внедрения деофшоризации на фондовом рынке Украины, представляет собой инструмент экономического механизма для обеспечения дальнейшего развития государственного регулирования фондового рынка, использованные при формировании предложения о введении деофшоризацию на фондовом рынке в Положении о Национальной комиссии по ценным бумагам и фондовом рынке. Значение/оригинальность. Внедрение деофшоризации на фондовом рынке позволит государству усилить защиту прав инвесторов, что является стратегической задачей Украины, а также поможет укрепить отечественный фондовый рынок и повысить уровень доверия к нему со стороны населения. 